\title{
AN EFFECT OF THE OUTPATIENT REHABILITATION PROGRAMME IN PATIENTS WITH CHRONIC RESPIRATORY DISEASES
}

\author{
Jakub Zatloukal ${ }^{1, *}$, Kateřina Neumannová ${ }^{1}$, Hana Olšáková ${ }^{1}$, Vítězslav Kolek ${ }^{2}$, \\ Jaromír Zatloukal'², Vladimíra Loštáková ${ }^{2}$, Jana Jašková
}

\author{
${ }^{I}$ Faculty of Physical Culture, Palacký University, Olomouc, Czech Republic \\ ${ }^{2}$ Faculty of Medicine and Dentistry, Palacký University, Olomouc, Czech Republic
}

Submitted in March, 2013

BACKGROUND: Pulmonary rehabilitation is a common type of complex treatment especially in patients with chronic obstructive pulmonary disease (COPD). By contrast, only few rehabilitation centres in the Czech Republic provide pulmonary rehabilitation programme to non-COPD patients.

OBJECTIVE: To find out if the rehabilitation programme has a similar effect in patient with obstructive and restrictive ventilatory disorder.

METHODS: Twenty-eight patients with either COPD or pulmonary sarcoidosis (PS) have been enrolled for the 6-week rehabilitation programme. Lung functions, maximal inspiratory (MIP) and expiratory (MEP) mouth pressures, chest expansion at the level of the 4th intercostal space (IC) and at the level of the xiphoid process (XP), sixminute walk test, health-related quality of life using the St. George's Questionnaire (SGRQ) and fatigue occurrence using the Multidimensional Assessment of Fatigue scale (MAF) were tested at the baseline and after 6 weeks. The rehabilitation programme consisted of exercise training, ventilatory muscle training, respiratory physiotherapy and soft-tissue techniques.

RESULTS: Patients with COPD improved significantly $(p<.05)$ in MIP by $17 \%\left(10.5 \mathrm{~cm} \mathrm{H}_{2} \mathrm{O}\right)$, MEP by $18 \%$ $\left(16.8 \mathrm{~cm} \mathrm{H} \mathrm{H}_{2} \mathrm{O}\right)$, IC by $65 \%(1.7 \mathrm{~cm}), \mathrm{XP}$ by $90 \%(1.9 \mathrm{~cm})$, six-minute walk distance (6MWD) by $15 \%(64.1 \mathrm{~m})$ and SGRQ by $-28 \%\left(-12.3\right.$ points). Patients with PS improved significantly $(p<.05)$ in MIP by $25 \%\left(20.1 \mathrm{~cm} \mathrm{H}_{2} \mathrm{O}\right)$, IC by $29 \%(1.3 \mathrm{~cm}), \mathrm{XP}$ by $29 \%(1.3 \mathrm{~cm})$ and $6 \mathrm{MWD}$ by $6 \%(31.6 \mathrm{~m})$. The change in lung functions and MAF in both groups; MEP and SGRQ in PS group were insignificant after the 6-week rehabilitation programme.

CONCLUSIONS: The 6-week rehabilitation programme produces similar responses in functional health status of patients with either obstructive or restrictive ventilatory disorder. However, patients with restrictive ventilatory disorder in particular should be encouraged to continue in the programme to enhance the health-related quality of life, which might not be sufficiently affected after 6 weeks.

Keywords: Physiotherapy, exercise training, COPD, pulmonary sarcoidosis, ventilatory disorder.

\section{INTRODUCTION}

Chronic respiratory disease is mostly represented by patients with chronic obstructive pulmonary disease (COPD), which is often presented with respiratory symptoms like dyspnoea, cough and chest pain; and systemic symptoms like inflammation, cardiovascular disorder, muscle dysfunction, fatigue, depression and weight loss. Altogether the symptoms are responsible for exercise intolerance, poor health status and decreased quality of life (GOLD, 2008; Kašák, 2011).

\footnotetext{
* Address for correspondence: Jakub Zatloukal is now at Department of Pulmonary Rehabilitation, University Hospitals of Leicester NHS Trust, Glenfield Hospital, Groby Road, Leicester LE3 9QP, UK. E-mail: jakub.zatloukal@uhl-tr.nhs.uk
}

Pulmonary rehabilitation is highly recommended in such patients to enhance the functional health status and quality of life (Ries et al., 2007). According to the guidelines the pulmonary rehabilitation involves participation of a multidisciplinary team and it is chiefly based on a medical intervention and rehabilitation programme, but also, if necessary, on oxygen supplementation, non-invasive ventilation, nutritional support, psychosocial support and surgery intervention including lung transplantation. The foundation of the rehabilitation programme is exercise training, strength training involving both respiratory and peripheral muscles, respiratory techniques and education. The programme should last at least for 6 weeks, although it has been shown that the longer the programme takes the longer its effects last (ATS/ERS, 2006; Ries et al., 2007). 
The similar health condition and a symptom occurrence as in COPD might be seen also in other respiratory diseases that have different pathomorphological basis such as interstitial lung diseases (ILD), which are characterized with a restrictive ventilatory disorder. The rehabilitation programme is recommended in ILD as well, although the recommendation lacks the quality of evidence (Wells \& Hirani, 2008) as the effect of the rehabilitation programme has been briefly studied in such population. As a consequence, ILD patients are less likely to be referred to attend the rehabilitation programme.

The aim of the study was to compare if the rehabilitation treatment provoke similar responses to the therapy on functional health status and health-related quality of life in patients with both obstructive and restrictive ventilatory disorder.

\section{METHODS}

\section{Study subjects}

Patients having either chronic obstructive pulmonary disease $(N=14$; aged $65.9 \pm 10.2)$ or pulmonary sarcoidosis $(N=14$; aged $52.1 \pm 10.3)$ attended a 6-week outpatient rehabilitation programme at the Department of Respiratory Medicine in the Teaching Hospital in Olomouc, Czech Republic. All participants agreed with the recruitment into the study and signed informed consent. At the time of the study, all patients were medically stable and receiving a proper medication in relation to their disease. None of the participants had previously undergone a rehabilitation programme for patients with chronic respiratory disease. The mean length of the standard health care was $7.3 \pm 3.8$ years in COPD and $4.8 \pm 3.7$ years in pulmonary sarcoidosis (PS) patients. The present stages of the disease were stage II and III in COPD (7 and 7 patients), and stage I, II and III in PS (1, 10 and 3 patients, respectively).

The study was approved by the Ethics Committee of the Faculty of Physical Culture of Palacký University in Olomouc, Czech Republic.

\section{Study design}

Patients were recruited for a 6-week outpatient rehabilitation programme, which was conducted individually twice a week under the supervision of a physiotherapist, who was also involved in the patient's assessments. Baseline and the following measurement after 6 weeks included lung function testing (ZAN 100 Handy USB, nSpire Health Inc.), maximal inspiratory (MIP) and expiratory (MEP) mouth pressure (Micro Respiratory Pressure Meter, Care Fusion), chest expansion assessed with a tape-cloth measure at the level of the 4th intercostal space (IC) and at the level of the xiphoid process (XP), and 6-minute walk test (6MWT). All as- sessments were conducted according to the standard protocols. Patients completed the St. George's Respiratory Questionnaire (SGRQ) and the Multidimensional Assessment of Fatigue Scale (MAF) for an evaluation of health-related quality of life and fatigue. The lower is the outcome value in either of the questionnaires, the better is the health-related quality of life or the lower is the presence of fatigue. Both instruments are presented with a validated translation for the Czech speaking patients and permission to use was given by their authors beforehand.

\section{Rehabilitation programme}

The rehabilitation programme consisted of exercise training, ventilatory muscle training, respiratory physiotherapy and soft-tissue techniques.

The exercise training comprised a 20-minute long physical activity three-times a week. Heart rate and oxygen saturation were monitored during the training unit. The intensity was set as $60 \%$ of the maximal heart rate reserve for the two supervised sessions on a stationary bicycle. For the unsupervised session, which was conducted in a home-setting using either Nordic walking or cycling, the intensity was based on a symptom-related evaluation using the 0-10 Borg Dyspnoea Scale that corresponded with points 4-6 of the scale.

Resistive breathing devices (Threshold Inspiratory Muscle Trainer, Threshold Positive Expiratory Pressure; Philips Respironics) were used for the ventilatory muscle training for 15 minutes daily starting the first week and for 30 minutes daily with each device afterwards until the end of the programme. The intensity was set as $30 \%$ of maximal inspiratory and expiratory mouth pressure.

Respiratory physiotherapy performed on a daily basis included specific breathing techniques like diaphragmatic breathing, pursed lip breathing and airway clearance techniques, but also an activation of the core muscle system and diaphragm in particular to enhance a postural functions and stability. Soft-tissue techniques using tension-release techniques for fascias and muscles were used daily as prevention for musculoskeletal imbalances and for influencing the rib cage mobility.

\footnotetext{
Analysis

Predicted values of MIP and MEP were computed using the Black and Hyatt equations (Cahalin, 2004); and of 6MWT using the 6MWT guideline (Chlumský, 2003). Descriptive characteristics and non-parametric test using the Wilcoxon signed-rank test were computed in Statistica 9.0 software. The significance was established as a $p<.05$.
} 


\section{RESULTS}

Baseline characteristics of COPD and PS patients are shown in the Table 1. Presented symptoms in both groups of patients comprised dyspnoea (100\% COPD and $86 \%$ PS patients), fatigue (64\% COPD and $43 \%$ PS patients) and cough (36\% COPD and 7\% PS patients) at the beginning of the study.

After the completion of the rehabilitation programme in COPD, an increase was seen in MIP by $17 \%\left(10.5 \mathrm{~cm} \mathrm{H}_{2} \mathrm{O} ; p=.002\right)$ and in MEP by $18 \%(16.8$ $\left.\mathrm{cm} \mathrm{H}_{2} \mathrm{O} ; p=.011\right)$. Chest expansion was improved at both IC level by $65 \%(1.7 \mathrm{~cm} ; p=.003)$ and XP level by $90 \%(1.9 \mathrm{~cm} ; p=.002)$. The 6MWD increased by $15 \%(64.1 \mathrm{~m} ; p=.012)$ and exceeded also the minimal clinically important difference (MCID), which is $54 \mathrm{~m}$ for COPD patients (Clini \& Crisafulli, 2009). Lung functions showed no significant improvement after the rehabilitation programme as $\mathrm{VC}$ increased by $0.4 \%$ ( $0.3 \%$ of predicted; $p=.753), \mathrm{FEV}_{1}$ by $2.9 \%$ (1.5\% of predicted; $p=.364)$ and PEF by $4.4 \%$ (2.5\% of predicted; $p=.701)$. Health-related quality of life assessed by the SGRQ improved significantly in the activity score by $-20 \%(-12.3$ points; $p=.015)$, in the impact score by $-36 \%(-12.5$ points; $p=.016)$ and in the total score by $-28 \%(-12.3$ points; $p=.005)$. The change in the symptom score lacked the statistical significance, although it changed by $-27 \%(-10.7$ points; $p=.087)$. However, the MCID for SGRQ, which is represented by a change of more than 4.0 points (Jones, 2005), was exceeded in all domains of the questionnaire in COPD patients. The presence of fatigue diminished without statistical significance as the MAF improved by $-7 \%$ $(-1.9$ points; $p=.158)$. The MCID for MAF questionnaire is a change of more than 5.0 points (Goligher et al., 2008).

The completion of the rehabilitation programme in PS induced significant changes in MIP, which increased by $25 \%\left(20.1 \mathrm{~cm} \mathrm{H}_{2} \mathrm{O} ; p=.003\right)$. MEP increased insignificantly by $5 \%\left(5.6 \mathrm{~cm} \mathrm{H}_{2} \mathrm{O} ; p=.198\right)$. Chest expansion improved significantly at both IC level by $29 \%(1.3 \mathrm{~cm} ; p=.002)$ and XP level by $29 \%$ $(1.3 \mathrm{~cm} ; p=.003)$. The 6MWD increased significantly by $6 \%(31.6 \mathrm{~m} ; p=.028)$ and the change reached the MCID for 6MWD, which is $30-33 \mathrm{~m}$ in patients with diffuse parenchymal lung disease (Holland, Hill, Conron, Munro, \& McDonald, 2009). Lung function showed no significant improvements after the rehabilitation programme. VC increased by $1.2 \%$ (1.2\% of predicted; $p=.422), \mathrm{FEV}_{1}$ decreased by $0.7 \%(-0.6 \%$ of predicted; $p=.972)$ and PEF by $3.4 \%(-2.7 \%$ of predicted; $p=.380$ ). Health-related quality of life using the SGRQ changed insignificantly in the symptom score by $3 \%$ ( 0.7 points; $p=.972)$, in the activity score by $-10 \%$ $(-4.7$ points; $p=.300)$, in the impact score by $-8 \%$ $(-2.1$ points; $p=.272)$ and in the total score by $-7 \%$
Table 1

Baseline characteristics (mean $\pm S D$ ) of participants

\begin{tabular}{|c|c|c|}
\hline & COPD & PS \\
\hline$N$ (female/male) & $14(7 / 7)$ & $14(10 / 4)$ \\
\hline Age (years) & $65.9 \pm 10.2$ & $52.1 \pm 10.3$ \\
\hline BMI & $27.7 \pm 5.4$ & $29.1 \pm 6.8$ \\
\hline VC $\%$ predicted & $85.3 \pm 17.9$ & $97.5 \pm 16.1$ \\
\hline $\mathrm{FEV}_{1} \%$ predicted & $51.4 \pm 20.8$ & $88.9 \pm 14.1$ \\
\hline PEF \% predicted & $56.3 \pm 23.5$ & $79.4 \pm 16.3$ \\
\hline \multicolumn{3}{|l|}{ MIP } \\
\hline $\mathrm{cm} \mathrm{H}_{2} \mathrm{O}$ & $61.0 \pm 26.4$ & $78.5 \pm 32.9$ \\
\hline$\%$ predicted & $70.8 \pm 29.9$ & $88.4 \pm 32.4$ \\
\hline \multicolumn{3}{|l|}{ MEP } \\
\hline $\mathrm{cm} \mathrm{H}_{2} \mathrm{O}$ & $94.1 \pm 37.8$ & $109.3 \pm 51.4$ \\
\hline$\%$ predicted & $58.2 \pm 22.6$ & $65.1 \pm 26.2$ \\
\hline \multicolumn{3}{|l|}{ Chest expansion $(\mathrm{cm})$} \\
\hline 4th intercostal space & $2.6 \pm 1.6$ & $4.5 \pm 1.6$ \\
\hline xiphoid process & $2.1 \pm 1.7$ & $4.5 \pm 1.6$ \\
\hline \multicolumn{3}{|l|}{ 6MWD } \\
\hline $\mathrm{m}$ & $425.9 \pm 122.0$ & $554.3 \pm 56.6$ \\
\hline$\%$ predicted & $97.6 \pm 30.8$ & $102.4 \pm 10.3$ \\
\hline \multicolumn{3}{|l|}{ SGRQ } \\
\hline total score & $43.8 \pm 16.0$ & $32.3 \pm 16.3$ \\
\hline symptom score & $40.3 \pm 28.4$ & $23.5 \pm 17.3$ \\
\hline activity score & $60.7 \pm 16.1$ & $48.3 \pm 22.4$ \\
\hline impact score & $35.1 \pm 15.9$ & $26.0 \pm 17.1$ \\
\hline MAF & $26.1 \pm 8.0$ & $23.4 \pm 8.4$ \\
\hline
\end{tabular}

Note. $\mathrm{COPD}=$ chronic obstructive pulmonary disease, $\mathrm{PS}=$ pulmonary sarcoidosis, BMI = body mass index, $\mathrm{VC}=$ vital capacity, $\mathrm{FEV}_{1}$ = forced expiratory volume in 1 second, $\mathrm{PEF}=$ peak expiratory flow, $\mathrm{MIP}=$ maximal inspiratory mouth pressure, $\mathrm{MEP}=$ maximal expiratory mouth pressure, $6 \mathrm{MWD}=$ six-minute walk distance, SGRQ = St. George's Respiratory Questionnaire (0-100), MAF $=$ Multidimensional Assessment of Fatigue Scale (0-50).

$(-2.4$ points; $p=.140)$. Even though that all domains of SGRQ lacked the statistical significance, the activity score exceeded the MCID for SGRQ. Fatigue assessed by MAF insignificantly diminished throughout the programme in PS by $-12 \%(-2.7$ points; $p=.158)$.

The treatment effect of the rehabilitation programme in both COPD and PS patients is shown in Figure 1.

\section{DISCUSSION}

The rehabilitation programme of the current study was founded on the pulmonary rehabilitation programme 


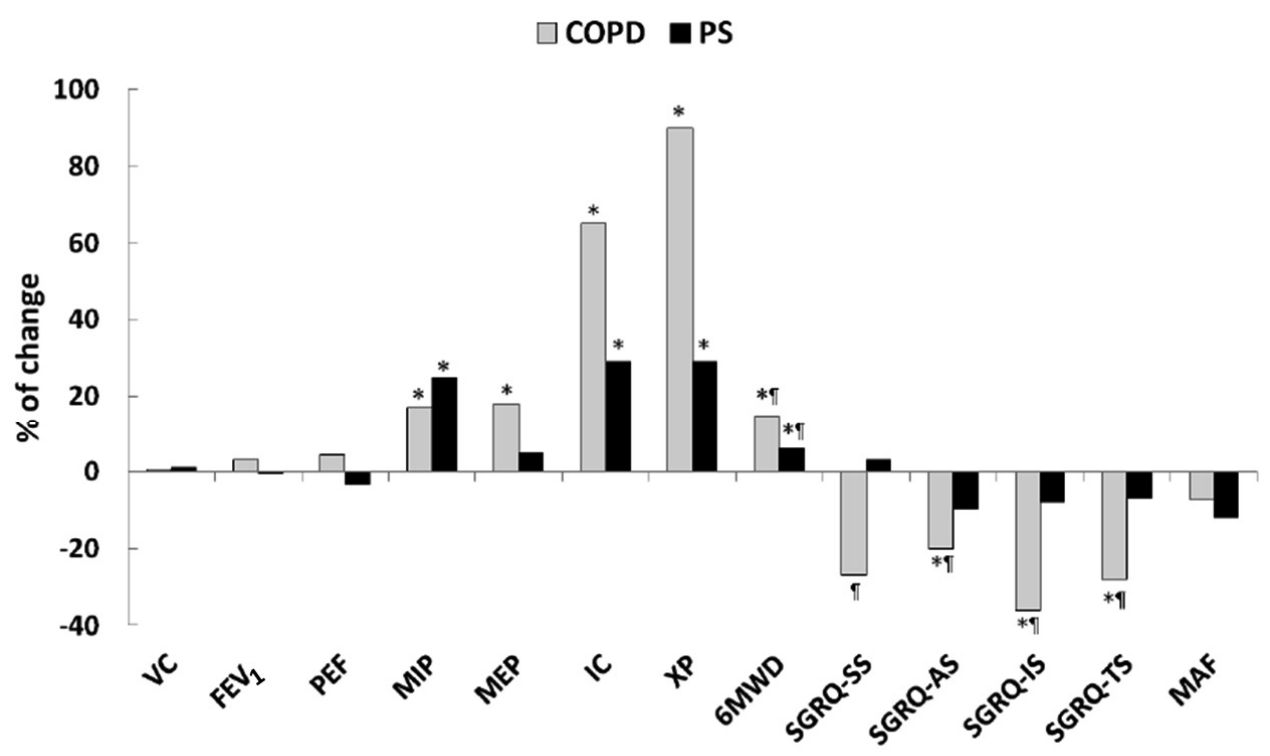

Figure 1. The treatment effect of the 6-week outpatient rehabilitation programme in patients with chronic obstructive pulmonary disease and pulmonary sarcoidosis. COPD = chronic obstructive pulmonary disease, PS = pulmonary sarcoidosis, $\mathrm{VC}=$ vital capacity, $\mathrm{FEV}_{1}=$ forced expiratory volume in 1 second, $\mathrm{PEF}=$ peak expiratory flow, $\mathrm{MIP}=$ maximal inspiratory mouth pressure, $\mathrm{MEP}=$ maximal expiratory mouth pressure, $\mathrm{IC}=$ chest expansion at the level of the 4th intercostal space, $\mathrm{XP}=$ chest expansion at the level of xiphoid process, $6 \mathrm{MWD}=6$-minute walk distance, SGRQ-SS = symptom score of the St. George's Respiratory Questionnaire, SGRQ-AS = activity score of the SGRQ, SGRQ-IS = impact score of the SGRQ, SGRQ-TS = total score of the SGRQ, MAF = Multidimensional Assessment of Fatigue Scale. ${ }^{*} p<.05, \mathbb{\Upsilon}=$ minimal clinically important difference.

definition according to the health care system of the Czech Republic. Therefore, the treatment that was applied to patients in this study is feasible in the clinical practice within the Czech Republic, and it can be prescribed by any physician, who wants to refer a patient with chronic respiratory disease to a rehabilitation programme.

The results of the study showed similar responses to the rehabilitation treatment that were assessed according to the functional health status in both groups of patients. The functional parameters that improved were the same in both groups, although the groups differed in age, the size of baseline values of functional parameters and health status, which are relevant to the size effect of the treatment (Troosters, Gosselink, \& Decramer, 2001). Chest expansion, inspiratory muscle strength and 6MWD improved significantly in both groups. Such results correspond with outcomes of other studies that had been evaluating the rehabilitation effect separately in COPD (Chlumský, Bláhová, \& Novotná, 2009; Neumannová, 2011) or ILD patients (Ferreira et al., 2009; Holland, Hill, Conron, Munro, \& McDonald, 2008). We quote clinical trials for ILD patients as, to our knowledge, there is no study evaluating the rehabilitation programme in pulmonary sarcoidosis patients rather than altogether with other ILD. It has been also described the relationship of inspira- tory muscle strength with dyspnoea sensation and the 6MWD (Gosselink et al., 2011; Kabitz et al., 2006), which are closely related, although the lung functions are the most influencing parameter for the 6MWD. Troosters, Gosselink, Janssens, and Decramer (2010) have notified that the lung functions are not influenced by the rehabilitation programme, but with the use of medication which has also effect on the inflammation and dynamic hyperinflation (DH) in those where $\mathrm{DH}$ is present. On the other hand, the rehabilitation programme regulates the symptom occurrence and systemic consequences by enhancing the functional health status of patients, which has been demonstrated in the current study.

Another parameter that has been changed in both groups was the health-related quality of life, although the changes were statistically and clinically significant only in the COPD group. Nevertheless, MCID for SGRQ in the activity score has been exceeded in both groups, which support the clinically significant change in 6MWD, which has been achieved in both groups. The clinical significance means that patients were self-aware about the change after the rehabilitation programme, but unfortunately that cannot be said about the occurrence of fatigue, though it diminished in both groups. Data suggest that the 6-week outpatient rehabilitation programme was of the appropriate dura- 
tion to evoke changes in functional health status and health-related quality of life in COPD patients, however not for patients with PS as the health-related quality of life was not that much improved although the change in functional health status was statistically and clinically relevant.

A possible explanation for this may be differences in baseline characteristics of the groups as PS patients did not show such functional impairment in lung functions, 6MWD or health-related quality of life like COPD patients, which also suggest different inclusion criteria for PS patients for future studies. It might be also concluded that PS patients need a longer programme or that they should be encouraged to continue themselves as other studies presented supportive results of improving all - the functional health status, the health-related quality of life and symptoms after the 8-week rehabilitation programme in ILD patients (Ferreira et al., 2009; Holland, Hill, Conron, Munro, \& McDonald, 2008), and yet again, the baseline characteristics of patients in these studies comprise patients having severer functional impairment of health status than the PS patient group of the current study. But despite that all the continuation in the programme should be encouraged in all patients as the longer the programme lasts the greater the change might be and the longer the patient might sustain its benefit (Ries et al., 2007).

\section{CONCLUSIONS}

The 6-week outpatient rehabilitation programme led to the similar responses in the functional health status of patients with chronic respiratory diseases with either obstructive or restrictive ventilatory disorder. For that reason the pulmonary rehabilitation programme should be prescribed not only for COPD, but also nonCOPD patients and PS, in particular, after a thorough consideration for referral to the pulmonary rehabilitation programme with regard to the expected treatment effect. Although the duration of the programme is satisfactory to clinically improve health-related quality of life in patients with obstructive ventilatory disorder, it should be further studied in non-COPD patients before a general recommendation can be made.

\section{ACKNOWLEDGMENT}

The study was supported by the project No. CZ.1.07/2.3.00/30.0004 and the grant of Palacký University No. FTK_2012:023.

\section{REFERENCES}

ATS/ERS. (2006). American Thoracic Society/European Respiratory Society statement on pulmonary rehabilitation. American Journal of Respiratory and Critical Care Medicine, 173, 1390-1413.

Cahalin, L. P. (2004). Pulmonary evaluation. In W. E. DeTurk \& L. P. Cahalin (Eds.), Cardiovascular and pulmonary physical therapy: an evidence-based approach (pp. 221-272). New York, NY: McGrawHill.

Chlumský, J. (2003). Standard pro šestiminutový test chưzi [Guidelines for the six-minute walk test]. Retrieved from http://www.pneumologie.cz/odborne/ doporucene-postupy.php

Chlumský, J., Bláhová, M., \& Novotná, Š. (2009). Fyziologický a klinický efekt ambulantní plicní rehabilitace u pacientů s chronickou obstrukční plicní nemocí [Physiological and clinical effects of outpatient pulmonary rehabilitation in patients with chronic obstructive pulmonary disease]. Studia pneumologica et phthiseologica, 69, 162-167.

Clini, E. M., \& Crisafulli, E. (2009). Exercise capacity as a pulmonary rehabilitation outcome. Respiration, 77, 121-128.

Ferreira, A., Garvey, C., Connors, G. L., Hilling, L., Rigler, J., Farrell, S., ... Collard, H. R. (2009). Pulmonary rehabilitation in interstitial lung disease: Benefits and predictors of response. Chest, 135, 442-447.

GOLD. (2008). Global initiative for chronic obstructive pulmonary disease. Retrieved from http://www.goldcopd.org/Guidelineitem. asp?11=2\&12=1\&intId=2003

Goligher, E. C., Pouchot, J., Brant, R., Kherani, R. B., Aviña-Zubieta, J. A., Lacaille, D., ... Liang, M. H. (2008). Minimal clinically important difference for 7 measures of fatigue in patients with systemic lupus erythematosus. Journal of Rheumatology, 35, 635-642.

Gosselink, R., De Vos, J., van den Heuvel, S. P., Segers, J., Decramer, M., \& Kwakkel, G. (2011). Impact of inspiratory muscle training in COPD: What is the evidence? European Respiratory Journal, 37, 416-425.

Holland, A. E., Hill, C. J., Conron, M., Munro, P., \& McDonald, C. F. (2008). Short term improvement in exercise capacity and symptoms following exercise training in interstitial lung disease. Thorax, 63, 549-554.

Holland, A. E., Hill, C. J., Conron, M., Munro, P., \& McDonald, C. F. (2009). Small changes in sixminute walk distance are important in diffuse parenchymal lung disease. Respiratory Medicine, 103, 1430-1435.

Jones, P. W. (2005). St. George's Respiratory Questionnaire: MCID. COPD: Journal of Chronic Obstructive Pulmonary Disease, 2, 75-79. 
Kabitz, H. J., Lang, F., Walterspacher, S., Sorichter, S., Muller-Quernheim, J., \& Windisch, W. (2006). Impact of impaired inspiratory muscle strength on dyspnea and walking capacity in sarcoidosis. Chest, 130, 1496-1502.

Kašák, V. (2011). Chronická obstrukční plicní nemoc [Chronic obstructive pulmonary disease]. In V. Kolek, V. Kašák, \& M. Vašáková (Eds.), Pneumologie (pp. 119-144). Praha: Maxdorf.

Neumannová, K. (2011). Rozvíjení hrudníku, ventilační parametry a vybrané kineziologické ukazatele u nemocných $\mathrm{s}$ asthma bronchiale a chronickou obstrukční plicní nemocí [Chest expansion, ventilatory parameters and selected kinesiologic indices in patients with bronchial asthma and chronic obstructive disease]. Rehabilitace a fyzikální lékařství, $18,132-137$.

Ries, A. L., Bauldoff, G. S., Carlin, B. W., Casaburi, R., Emery, C. F., Mahler, D. A., ... Herrerias, C. (2007). Pulmonary rehabilitation: Joint ACCP/ AACVPR evidence-based clinical practice guidelines. Chest, 131(Suppl. 5), 4-42.

Troosters, T., Gosselink, R., \& Decramer, M. (2001). Exercise training in COPD: How to distinguish responders from nonresponders. Journal of Cardiopulmonary Rehabilitation, 21, 10-17.

Troosters, T., Gosselink, R., Janssens, W., \& Decramer, M. (2010). Exercise training and pulmonary rehabilitation: New insights and remaining challenges. European Respiratory Review, 19, 24-29.

Wells, A. U., \& Hirani, N. (2008). Interstitial lung disease guideline. Thorax, 63(Suppl. 5), 1-58.

\section{VLIV AMBULANTNÍ REHABILITAČNÍ LÉČBY NA PACIENTY S CHRONICKÝM RESPIRAČNÍM ONEMOCNĚNÍM}

(Souhrn anglického textu)

VÝCHODISKA: Plicní rehabilitace představuje komplexní léčebnou péči zejména u pacientů s chronickou obstrukční plicní nemocí (CHOPN). Naproti tomu je v České republice jen málo pracovišt', která rehabilitační léčbu poskytují také pacientům s jiným respiračním onemocněním.
CÍLE: Cílem studie bylo zjistit, jestli je terapeutický efekt rehabilitační léčby u jedinců s obstrukční a restrikční ventilační poruchou podobný.

METODIKA: Dvacet osm pacientů s CHOPN a plicní formou sarkoidózy (PS) podstoupilo šestitýdenní ambulantní rehabilitační léčbu. Vstupní a výstupní vyšetření zahrnovalo testování plicních funkcí, vyšetření maximálních nádechových (MIP) a výdechových (MEP) ústních tlaků, rozvíjení hrudníku ve výši 4. mezižebří (IC) a ve výši processus xiphoideus (XP), šestiminutový test chủzí, hodnocení kvality života ve vztahu ke zdraví pomocí dotazníku St. George's Respiratory Questionnaire (SGRQ) a hodnocení symptomu únavy pomocí dotazníku Multidimensional Assessment of Fatigue scale (MAF). Rehabilitační program obsahoval vytrvalostní trénink, trénink síly dýchacích svalů, respirační fyzioterapii a měkké a mobilizační techniky. VÝSLEDKY: Pacienti s CHOPN se po absolvování rehabilitačního programu významně zlepšili $(p<0,05)$ v MIP o $17 \%\left(10,5 \mathrm{~cm} \mathrm{H}_{2} \mathrm{O}\right)$, MEP o $18 \%(16,8 \mathrm{~cm}$ $\left.\mathrm{H}_{2} \mathrm{O}\right)$, v IC o $65 \%(1,7 \mathrm{~cm})$, v XP o $90 \%(1,9 \mathrm{~cm})$, $\mathrm{v}$ př̀konané vzdálenosti během šestiminutového testu chůzí (6MWD) o $15 \%(64,1 \mathrm{~m})$ a v SGRQ o $-28 \%$ $(-12,3$ bodu). Pacienti s PS se významně zlepšili $(p<0,05)$ v MIP o $25 \%\left(20,1 \mathrm{~cm} \mathrm{H}_{2} \mathrm{O}\right)$, v IC o $29 \%$ $(1,3 \mathrm{~cm})$, v XP o $29 \%(1,3 \mathrm{~cm})$ a $v 6 \mathrm{MWD}$ о $6 \%$ (31,6 m). Změna plicních funkcí a MAF u obou skupin; MEP a SGRQ u PS skupiny nebyla po absolvované rehabilitační léčbě signifikantní.

ZÁVĚRY: Ambulantní rehabilitační léčba vyvolává obdobnou změnu ve funkčním hodnocení zdravotního stavu jak u pacientů s obstrukční, tak i restrikční ventilační poruchou. Nicméně pacienti by ale měli být nadále motivováni $\mathrm{k}$ pokračování $\mathrm{v}$ léčbě, aby došlo také ke zlepšení kvality života ve vztahu ke zdraví, která, zejména u pacientů s jiným onemocněním než CHOPN, nemusí být po šestitýdenní rehabilitační léčbě ovlivněna.

Klićová slova: fyzioterapie, pohybová léčba, chronická obstrukční plicní nemoc, plicní forma sarkoidózy, ventilační porucha. 